\title{
Effects of decreasing acid deposition and climate change on acid extremes in an upland stream
}

\author{
C. D. Evans, B. Reynolds, C. Hinton, S. Hughes, D. Norris, S. Grant, and B. Williams \\ Centre for Ecology and Hydrology, Deiniol Road, Bangor, LL57 2UP, UK
}

Received: 30 October 2006 - Published in Hydrol. Earth Syst. Sci. Discuss.: 11 September 2007

Revised: / - Accepted: / - Published: 5 March 2008

\begin{abstract}
This study assesses the major chemical processes leading to acid extremes in a small, moorland stream in midWales, UK, which has been monitored since 1979. Results suggest that base cation (mainly calcium) dilution, the "seasalt effect", and elevated nitrate pulses, are the major causes of seasonal/episodic minima in acid neutralising capacity (ANC), and that the relative importance of these drivers has remained approximately constant during 25 years of decreasing acid deposition and associated long-term chemical recovery. Many of the chemical variations causing short-term reductions in stream acidity, particularly base cation dilution and organic acid increases, are closely related to changes in water-flowpath and therefore to stream discharge. Changes in the observed $\mathrm{pH}$-discharge relationship over time indicate that high-flow $\mathrm{pH}$ has increased more rapidly than meanflow $\mathrm{pH}$, and therefore that episodes have decreased in magnitude since 1980. However a two-box application of the dynamic model MAGIC, whilst reproducing this trend, suggests that it will not persist in the long term, with mean ANC continuing to increase until 2100, but the ANC of the upper soil (the source of relatively acid water during high-flow episodes) stabilising close to zero beyond 2030. With climate change predicted to lead to an increase in maximum flows in the latter half of the century, high-flow related acid episodes may actually become more rather than less severe in the long term, although the model suggests that this effect may be small. Two other predicted climatic changes could also detrimentally impact on acid episodes: increased severity of winter "sea-salt" episodes due to higher wind speeds during winter storms; and larger sulphate pulses due to oxidation of reduced sulphur held in organic soils, during more extreme summer droughts. At the Gwy, the near-coastal location and relatively small extent of peat soils suggest that sea-salt episodes may have the greatest influence.
\end{abstract}

Correspondence to: C. D. Evans

(cev@ceh.ac.uk)

\section{Introduction}

\subsection{Importance of acid episodes}

Deposition of acidifying pollutants has led to declines in mean $\mathrm{pH}$ and acid neutralising capacity (ANC), and elevated concentrations of aluminium, in lakes and streams draining poorly buffered catchments. At the most severe levels of acidification (e.g. mean $\mathrm{ANC}<0$ ), the water body may no longer be able to sustain viable populations of sensitive organisms such as salmonid fish, and the system may be termed "chronically acidified". However, many surface waters that are not chronically acidified are subject "acid episodes". These are transient periods of elevated acidity, in general linked to variations in climate and hydrology, that may have detrimental ecological consequences. Acid episodies are widespread in geologically sensitive surface waters across Europe and North America (Wigington et al., 1992; Davies et al., 1992), are generally more severe where catchments have been subject to acid deposition, and may be the critical influence on survival of fish and other aquatic biota (e.g. Baker et al., 1990, 1996; Carline et al., 1992) The role of episodes is most pronounced in streams, where rapid changes in discharge can cause a shift from well-buffered baseflow to highly acidic stormflow. Lakes, although typically less affected by rapid chemical variation due to in-lake mixing, may still be subject to periods of elevated acidity (Davies et al., 1992).

With many surface waters in Europe now recovering from the extremes of acidification experienced during the 1970s and 1980s (e.g. Evans et al., 2001a; Skjelkvåle et al., 2005), incidence of chronic acidification has decreased. However, the extent and rapidity of biological recovery in these systems may be constrained by the continuation of transient periods of acidity in excess of biologically damaging thresholds. To an extent, the shift from chronically acidic to seasonally/episodically acidic surface waters can be considered

Published by Copernicus Publications on behalf of the European Geosciences Union. 
an inherent, intermediate stage of the recovery process. Where soil base status is slow to recover following reductions in deposition, this stage may be extended over many years (Lawrence, 2002). Finally, with the potential for longterm changes in climate, and in particular changes in climatic extremes, there is a risk that the frequency, timing, duration and intensity of acidic episodes may change. In the worst case, it is possible that improvements in mean water quality brought about by emissions reductions could be offset by worsening extremes, potentially reducing or negating the biological benefits of these reductions for aquatic biota.

\subsection{Causes of acid episodes}

The most widespread driver of reductions in ANC is the dilution of base cation concentrations during high flow events, as dominant sources of runoff shift from deeper, base-rich flowpaths to more acidic shallow subsurface or surface pathways (Wigington et al., 1990, 1992; Davies et al., 1992). Base cation dilution can reduce ANC, but cannot cause acid episodes with ANC below zero in the absence of elevated strong acid anion concentrations. Dilution episodes are most commonly associated with rain events, but may also occur (potentially more severely, and over longer durations) during snowmelt. Given the importance of hydrology, increases in the magnitude and frequency of extreme rain or snowmelt events due to climate change could influence the severity of acidic episodes associated with base cation dilution, either by increasing water transported via shallow soil horizons or overland flow, or by progressively depleting the store of base cation buffering within the catchment.

Acid episodes may also be caused, or intensified, by shortterm increases in acid anions. Episodic sulphate $\left(\mathrm{SO}_{4}\right)$ increases may occur where concentrations are relatively high in shallow soil horizons, for example in mineral soils where sulphur (S) adsorption occurs at depth (e.g. DeWalle and Swistock, 1994) or in snowmelt events where $\mathrm{SO}_{4}$ is released from the snowpack (e.g. Molot et al., 1989). Less frequent, but potentially more severe $\mathrm{SO}_{4}$ pulses occur in waters draining organic soils, where $\mathrm{S}$ can accumulate over long periods (in organic S compounds or sulphides) through biological reduction in wet, anaerobic soils, and then be released by re-oxidation during dry periods and subsequent flushing. This process has been clearly demonstrated in parts of Canada (e.g. Bayley et al., 1986; Dillon et al., 1997), where large, cyclical fluctuations in $\mathrm{SO}_{4}$ linked to drought occurrence (and, indirectly, to the El Niño Southern Oscillation) have in some cases largely obscured any long-term recovery due to reduced $\mathrm{S}$ deposition. Similar $\mathrm{SO}_{4}$ pulses following drought years have also been observed in peatland areas of the UK (Hughes et al., 1997; Adamson et al., 2001; Bottrell et al., 2004), and where large stores of reduced S have accumulated, droughts may continue to cause acidifying $\mathrm{SO}_{4}$ pulses in future. Increased frequency and severity of droughts would be expected to exacerbate this process.
A range of mechanisms can give rise to nitrate $\left(\mathrm{NO}_{3}\right)$ pulses, including simple flowpath effects where $\mathrm{NO}_{3}$ concentrations are higher in shallow soils (e.g. Stoddard and Murdoch, 1991; Kahl et al., 1992); snowmelt (e.g. Schofield et al., 1985; Davies et al., 1992); and winter freezing events (Mitchell et al., 1996; Monteith et al., 2000). Winter $\mathrm{NO}_{3}$ pulses appear most significant, as they tend to coincide with seasonal $\mathrm{pH}$ minima. The relative influence of different mechanisms and climatic drivers varies according to location, so for example soil freezing events occur during the coldest winters in the UK (Monteith et al., 2000), whereas in areas with seasonal snowpacks, soil freezing occurs when decreased snow accumulation reduces the level of soil insulation (Mitchell et al., 1996). Therefore, while it is difficult to generalise about the impact of climate change on nitrateinduced acidic episodes, climate is clearly a key influence on the processes involved.

Episodic increases in organic acids are characteristic of many surface waters, since dissolved organic matter is produced in organic-rich near-surface soils, but typically retained during flow through deeper mineral soils. They have been shown to be important causes of $\mathrm{pH}$ depression in organic-rich systems, such as those in eastern Canada (Kerekes and Freedman, 1989) and Northern Sweden (Laudon et al., 2000). Climate change could significantly influence episodic organic acid concentrations by altering rates of DOM production (e.g. Freeman et al., 2001; Evans et al., 2005), or by altering dominant flowpaths (e.g. Schindler et al., 1997; Clair et al., 1999). However the biological role of DOM and organic acids during episodes is somewhat uncertain, since they may both raise acidity, but simultaneously (by forming organic complexes with $\mathrm{Al}$ ) reduce the toxicity of this acidity.

Finally, the "sea-salt effect" is an important driver of acid episodes in exposed coastal regions, notably west-coast areas of the British Isles, Norway and Sweden (Harriman and Wells, 1985; Langan, 1989; Skartveit, 1981; Wright et al., 1988), and the northern Atlantic coast of North America (Heath et al., 1992). The sea-salt effect is caused by marine salts, entrained into the atmosphere from breaking waves, being deposited onto catchment soils. Where these soils are acid, sea-salt cations (mainly sodium, $\mathrm{Na}$, and magnesium, $\mathrm{Mg}$ ) can displace the acid cations hydrogen $(\mathrm{H})$ and aluminium ( $\mathrm{Al}$ ) from exchange surfaces, leading to acidic episodes in runoff. Sea-salt episodes are evident in stream monitoring records as increases in chloride $(\mathrm{Cl})$, smaller increases in $\mathrm{Na}$ and $\mathrm{Mg}$ (i.e. by less than the $\mathrm{Na}: \mathrm{Cl}$ and $\mathrm{Mg}: \mathrm{Cl}$ ratios in seawater) and increases in $\mathrm{H}$ and $\mathrm{Al}$. The most extreme examples of seasalt episodes have been shown to cause depressions in $\mathrm{pH}$ and ANC for a year or more (Hindar et al., 1994; Evans et al., 2001b), in some cases leading to fish kills and other biological damage (Hindar et al., 1994). Conditions generating major seasalt deposition events are typically winter westerly and southwesterly gales, and links have consequently been demonstrated between the occurrence of 
seasalt episodes and the North Atlantic Oscillation (NAO) for both the UK (Evans et al., 2001b) and Norway (Hindar et al., 2004). Forecasted increases in the mean winter NAO Index, indicating a change towards more "westerly" dominated weather (Hulme et al., 2002), therefore suggest that seasalt episodes may also increase in severity in future.

In summary, a range of hydrological and biogeochemical processes can contribute to acidic episodes. These processes do not operate exclusively, and all are affected by both the long-term acidification status and history of the system, and by one or more climatic drivers. It is therefore impossible to consider either acid deposition or climate in isolation when analysing their influence on chemical and biological extremes in acid systems.

\subsection{Modelling acidic episodes}

Most acidification models operate on a yearly timestep, and thus provide an estimate of the annual mean chemistry associated with a given level of deposition; simulation of biologically-important extreme chemistry therefore represents a significant challenge. Attempts to predict future extremes in water chemistry have typically combined a yearlytimestep model of mean water chemistry with an empiricallybased description of short-term chemical variability. Jakeman et al. (1990) fitted probability distributions to two years of alkalinity data, and combined these with long-term chemical simulations generated using the MAGIC model. A previous study at the Afon Gwy, Wales (Robson et al., 1991; Neal et al., 1992) applied MAGIC in a two-layer mode, with the two layers representing chemical end-members of shallow soil throughflow and deeper groundwater, defined from stream and soil-water chemical data. By defining the proportion of each water source contributing runoff at a given stream discharge, Neal et al. (1992) were able to use a mixing model to predict episodic extremes in streamwater chemistry in different years, assuming the same hydrological sequence for each year. A later application of MAGIC to the Gwy (Evans, 2005) attempted to incorporate possible effects of climate change on stream acidity via changes in sea-salt deposition and soil organic acid generation. However this exercise was limited to simulating variations in annual mean chemistry, rather than simulating the influence of climate change on sub-annual chemical variability.

The aims of this study are to: elucidate the major drivers of chemical extremes in an upland catchment based on a long hydrological and chemical monitoring dataset; assess how the nature and strength of these episodic drivers has changed over 25 years of monitoring; and provide some prediction of the future severity of acid extremes under (i) reduced acid deposition, and (ii) changing climate. Since no long-term datasets are available with a sufficient time resolution to examine temporal changes in the the character of individual episodes, the approach used is to examine temporal changes in the extremes of acidity recorded within a dataset of weekly-to-monthly spot sampled chemistry, and in the drivers of these extremes. This should be considered a first step towards a full analysis of temporal trends in discrete episodes. Wright (2008) provides an assessment of the extent to which periodic spot-sampled chemistry provides an adequate measure of extremes at Birkenes, Norway, suggesting that weekly sampling is sufficient to capture chemical extremes at this site.

\section{Site description and long-term trends}

The Afon Gwy $\left(3^{\circ} 41^{\prime} \mathrm{W}, 52^{\circ} 27^{\prime} \mathrm{N}\right)$ is a headwater stream of the River Wye, forming part of the Plynlimon research area in mid-Wales, which has been intensively studied since the 1970s (Neal, 1997). The stream drains a $3.9 \mathrm{~km}^{2}$, acidsensitive moorland catchment, with an altitude range of 440$730 \mathrm{~m}$. Soils are mainly peats and peaty podzols, and vegetation is predominantly acid grassland, with heather on hilltop peats. The site has a temperate-maritime climate, so that prolonged snowpack accumulation, and snowmelt events, have a minor influence on the stream.

Stream chemical sampling began at the end of 1979 and, apart from a break during 1982, continues to the present day. Sampling intensity has varied, with near-weekly sampling until 1989, less frequent sampling (minimum monthly) from 1990 to 1996 , and 1-2 weekly sampling to 2005. Discharge was measured throughout the period at a steep stream flume structure, with stage levels measured every $5 \mathrm{~min}$ (averaged to $15 \mathrm{~min}$ ) by two independent Campbell Scientific CR10 data loggers connected to a shaft encoder with a float and weight. All chemical analyses were done at the Centre for Ecology and Hydrology, Bangor. $\mathrm{Na}$ and $\mathrm{K}$ were analysed by flame atomic emission spectrophotometry; $\mathrm{Ca}$ and $\mathrm{Mg}$ by flame atomic absorption spectrophotometry; acid anions by ion chromatography; dissolved organic carbon (DOC) by Autoanalyser using a UV-digestion technique and colorimetric detection; and alkalinity by Gran titration. Some changes in method have occurred since the inception of monitoring, most notably for sulphate $\left(\mathrm{SO}_{4}\right)$, which was analysed using a barium chloride turbidimetric method until autumn 1984. Alkalinity was measured using a fixed end-point titration until autumn 1991.

The Gwy is moderately acidic, with a mean $\mathrm{pH}$ of 5.68 in 2000-2003, and a mean charge balance acid neutralising capacity (ANC, calculated as the sum of base cations minus the sum of acid anions) of $18 \mu \mathrm{eq} \mathrm{I}^{-1}$ for the same period. $\mathrm{SO}_{4}$ (2000-2003 mean $55 \mu \mathrm{eq}^{-1}$ ) is the major acidifying anion. Long-term data (Fig. 1) provide some evidence of chemical recovery due to reductions in acid deposition since the 1970s. The early non-marine sulphate $\left(\mathrm{xSO}_{4}\right)$ record is noisy, becoming more stable after the change in analytical method in 1984, but overall there is clear evidence of a decline in concentrations. The other major pollutant anion, $\mathrm{NO}_{3}$, shows no clear trend. Although on average $\mathrm{NO}_{3}$ makes a minor 
(a) $\mathrm{pH}$

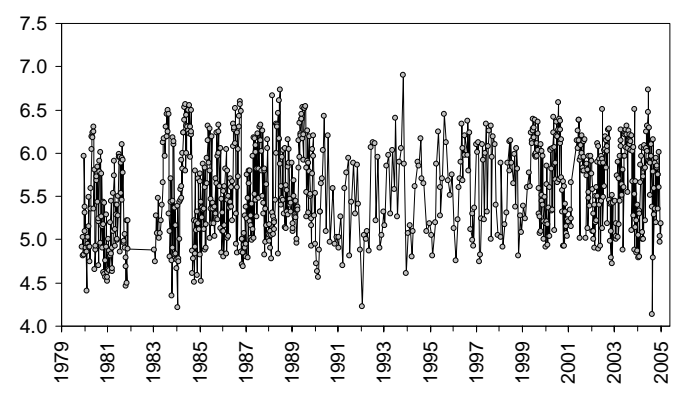

(c) Non-marine sulphate

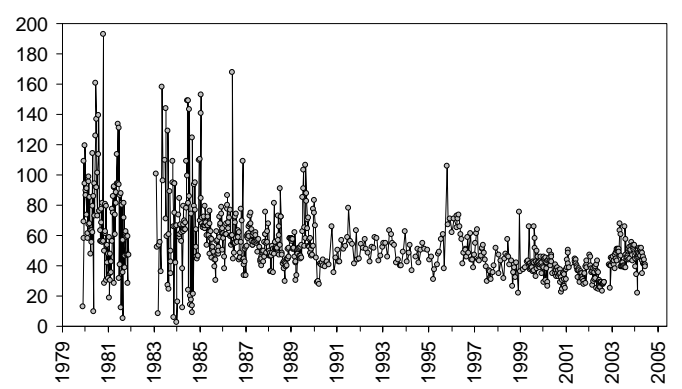

(e) Calcium

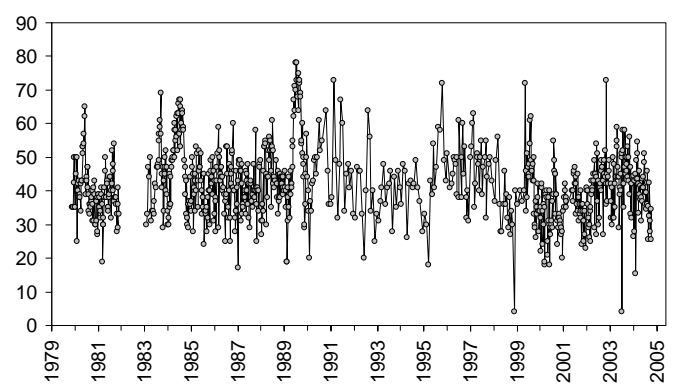

(b) Charge balance ANC

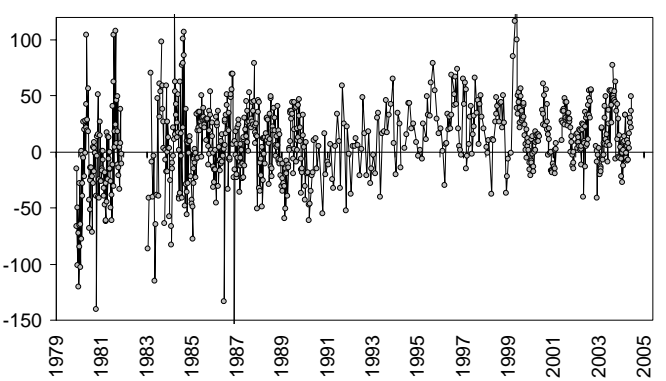

(d) Nitrate

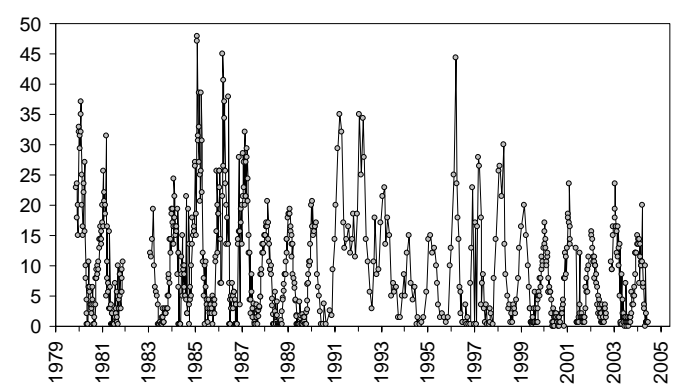

(f) Chloride

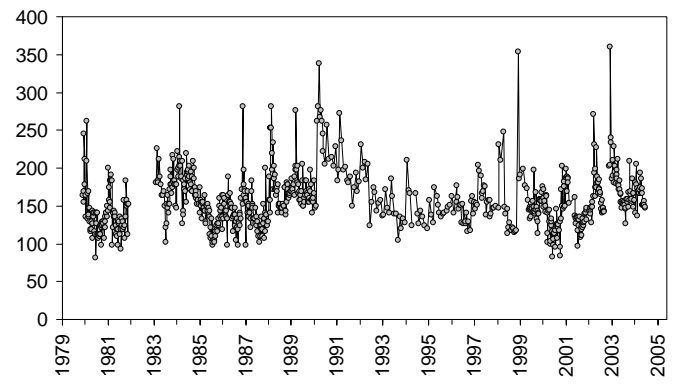

Fig. 1. Time series of some key chemical variables at the Afon Gwy, over the full monitoring period (all $\mu \mathrm{eq} \mathrm{l}^{-1} \mathrm{except} \mathrm{pH}$, in $\mathrm{pH}$ units).

contribution to reducing ANC, this anion has a strong seasonal cycle with high concentrations in winter. Variation in the magnitude of seasonal peaks is believed to be related to winter severity, with higher concentrations during cold winters (Monteith et al., 2000). High $\mathrm{Cl}$ concentrations, derived from deposition of marine ions, reflect the proximity of the site to the coast $(20 \mathrm{~km}$ west of the catchment). Decadalscale cycles in winter storm severity affect sea-salt deposition, as is evident in the $\mathrm{Cl}$ record. This variability is believed to have a significant impact on stream acidity (Evans et al., 2001b), most notably at the Gwy during 1990-1991.

The underlying trend in stream acidity at the Gwy is expected to be towards an increase in $\mathrm{pH}$ and $\mathrm{ANC}$, driven by the reduction in $\mathrm{xSO}_{4}$ (there is no clear trend in $\mathrm{NO}_{3}$ ). This recovery trend was simulated by Jenkins et al. (1997) using the MAGIC dynamic acidification model (Cosby et al., 2001), which predicted significant further recovery as $\mathrm{S}$ deposition declines in future. However upward trends in $\mathrm{pH}$ and $\mathrm{ANC}$ are difficult to detect in the observed time- series, in part due to natural temporal variability on several temporal scales. At the inter-annual scale, for example, variations in seasalt deposition and winter nitrate peaks are related to cyclical fluctuations in winter temperature and storminess. At a sub-annual scale, seasonal variations in many ions, including nitrate and seasalts, result in negative stream ANC during a part of all years of monitoring, with the most acid conditions typically occurring during winter. Finally, episodic variations cause short-term chemical variation. This is most evident in the $\mathrm{pH}$ record (Fig. 1a), in which changes of $>1 \mathrm{pH}$ unit between successive samples occur on over 40 occasions. On all of these temporal scales, the underlying drivers of chemical variation are associated with climatic factors; the capacity for climate change to influence the chemistry (and biology) of upland streams such as the Gwy is therefore large. 


\section{Methods}

\subsection{Chemical drivers of acidic extremes}

Various methods have been applied to identify the causes of short term acidification. In general, these methods attribute change in either Acid Neutralising Capacity (ANC) or alkalinity (measured by Gran titration) to changes in strong base cations and acid anions. Alkalinity data prior to 1991 at the Gwy (measured by fixed end-point titration) were inadequate for this analysis, and charge balance ANC was therefore used, calculated as (in $\mu$ eq $1^{-1}$ ):

$\mathrm{ANC}=\mathrm{Ca}^{2+}+\mathrm{Mg}^{2+}+\mathrm{Na}^{+}+\mathrm{K}^{+}+\mathrm{NH}_{4}^{+}-\mathrm{SO}_{4}^{2-}-\mathrm{NO}_{3}^{-}-\mathrm{Cl}^{-}$

Charge balance ANC has the advantage that, since it is defined by the balance of base cations and acid anions, changes in ANC can be precisely attributed to the changes in each of these constituent ions. A disadvantage is that organic acids do not form part of the ANC calculation, and are therefore omitted from the analysis. Previous studies have in some cases shown that they may contribute significantly to acid episodes when defined in terms of $\mathrm{pH}$ or alkalinity (e.g. Laudon et al., 2000), and the role of organic acids at the Gwy is considered later.

From Eq. (1), a decrease in ANC during the episode ( $\triangle \mathrm{ANC}$ ) is a function of the changes in each base cation $(\Delta \mathrm{Bc})$ and each acid anion $(\triangle \mathrm{Aa})$. Their proportional contributions to the ANC decrease may be defined as:

$\mathrm{dBc}=\Delta \mathrm{Bc} / \Delta \mathrm{ANC}$

and:

$\mathrm{dAa}=-\Delta \mathrm{Aa} / \Delta \mathrm{ANC}$

This method was applied by Molot et al. (1989) to the analysis of individual episodes in streams in Ontario, and has subsequently been applied similarly in a number of studies (e.g. Schaefer et al., 1990; Murdoch and Stoddard, 1993; DeWalle and Swistock, 1994). For long-term datasets in which sampling is relatively infrequent (e.g. monthly) it is difficult to capture pre-episode and peak-episode conditions, but these data may still provide valuable information on chemical extremes (e.g. VanSickle et al., 1997). The approach above has been adapted for long time-series data by analysing the average ionic changes between a set of "baseflow" and "episode" samples (Evans et al., 1995). This approach overcomes some of the limitations of long-term monitoring datasets, since it does not depend on the capture of individual episodes. By providing an averaged estimate of the chemical changes causing ANC reductions, it is also relatively insensitive to random error in the determination of individual cations and anions used to calculate ANC. Some care is required in interpreting results using this method, however, since both episodic and seasonal variations may be incorporated. "Baseflow" and "episode" samples can be
Table 1. Samples and time periods used for each analysis.

\begin{tabular}{ccc}
\hline \multicolumn{3}{c}{ (a) Analysis of chemical drivers of acidic extremes } \\
\hline Period & "Acid" samples & "Non-acid" samples \\
\hline $1985-1990$ & 83 & 84 \\
$1994-1999$ & 28 & 27 \\
$2000-2004$ & 50 & 45 \\
\hline
\end{tabular}

(b) Analysis of temporal trends in acidic extremes

\begin{tabular}{cc}
\hline Period & Number of samples \\
\hline $1979-1984$ & 192 \\
$1985-1989$ & 244 \\
$1990-1994$ & 70 \\
$1995-1999$ & 108 \\
$2000-2004$ & 245 \\
\hline
\end{tabular}

defined either in terms of discharge (e.g. samples collected during upper and lower quartile flows), or in terms of chemistry. Although discharge is more appropriate to the definition of flow-related variability, this approach risks excluding periods of high acidity at moderate flows, for example $\mathrm{SO}_{4}$-driven episodes during the first wet period following a drought. Therefore, a chemical definition was used, based on samples within the upper and lower quartiles of $\mathrm{pH}$ over the sampling period to define "non-acid" and "acid" samples respectively (Table 1). The choice of $\mathrm{pH}$ was based on its biological significance, and to minimise the risk of selecting anomalous samples (for example, a sample with an erroneously high measured $\mathrm{SO}_{4}$ concentration would have an erroneously low calculated $\mathrm{ANC}$, whereas $\mathrm{pH}$ would be unaffected). Data collected prior to the change in $\mathrm{SO}_{4}$ analytical method were excluded from the analysis, and data were divided into three blocks during which sampling frequency was greater than monthly: 1985-1990, 1994-1999, and 2000-2004.

\subsection{Temporal changes in episode severity}

As systems recover from acidification, it is likely that equivalent climatic events at different stages of the recovery process will generate differing chemical extremes. Thus, for example, knowledge of the maximum acidity associated with a given discharge peak at present day is insufficient to allow the acidity associated with the same discharge in the past or future to be accurately predicted. The long monitoring datasets available allow long-term changes in the relationship between episode chemistry and mean chemistry to be examined. Due to the innaccurate pre-1985 $\mathrm{SO}_{4}$ record, this analysis was undertaken using $\mathrm{pH}$ rather than charge balance ANC. The monitoring record was divided into five-year periods and the $\mathrm{pH}$-discharge relationship within each block was analysed. Where acid episodes are primarily influenced by 
Table 2. Observed $\mathrm{pH}$ during three periods of monitoring.

\begin{tabular}{cccc}
\hline Percentile & 1985-1990 & 1994-1999 & 2000-2004 \\
\hline 10th & 4.87 & 5.05 & 5.02 \\
25th & 5.13 & 5.24 & 5.23 \\
50th & 5.48 & 5.73 & 5.72 \\
75th & 6.04 & 6.10 & 6.07 \\
90th & 6.30 & 6.25 & 6.25 \\
\hline No. samples & 348 & 119 & 216 \\
\hline
\end{tabular}

hydrological flowpath, a correlation will be obtained between $\mathrm{pH}$ and discharge. Analysis of five five-year periods provided sufficient data to estimate a $\mathrm{pH}$-discharge relationship for each period (Table 1), and sufficient time-periods to examine long-term changes in this relationship. For each five-year period, the $\mathrm{pH}$-discharge regression relationship obtained was used to estimate the $\mathrm{pH}$ associated with mean flow (based on the full daily discharge record for 1979-2004) together with $\mathrm{pH}$ at a range of discharge percentiles.

\subsection{Predicting future acidic extremes}

To estimate the possible future severity of flow-related episodes, a previous one-box calibration of the MAGIC model (Evans, 2005) was revised to include two soil boxes. Following the procedure of Neal et al. (2002), an upper soil box ("soilwater") was defined as the Oh, E and Bs horizons of the peaty podzol soils that dominate the catchment. The lower soil box was defined as the $\mathrm{C}$ horizon and underlying regolith ("groundwater"). Due to the presence of an impeding ironpan layer, $48 \%$ of runoff was considered to derive from direct lateral soil water throughflow into the stream, the remaining 52\% from groundwater (Neal et al., 1992; Boorman et al., 1995). The chemistry of each soil box was derived from soil profile data described by Reynolds (1997). Other model input data, including deposition sequences, were taken from the single-box MAGIC application described in detail by Evans (2005). Briefly, the model was calibrated to mean observed stream chemistry (1999 reference year) and to observed exchangeable base cation fractions and $\mathrm{pH}$ in each soil box. This was done by adjusting base cation weathering rates, initial exchangeable base cation fractions and soilwater organic acid concentrations. The proportion of total weathering occurring in the upper soil box was manually calibrated to fit a 10-year (1985-1994) record of B horizon soil solution base cation concentrations from the site modelled by Reynolds (1997). Sulphate output fluxes were assumed to be approximately equal to inputs on a year-to-year basis, on the basis of flux analyses (Cooper, 2005) and low measured $\mathrm{S}$ adsorption capacity to in catchment soils (S. Hughes, unpublished data). However, because measured stream $\mathrm{SO}_{4}$ fluxes exceed those from the base of the soil profile, the dif- ference between the two was assumed to result from sulphide weathering, and included as a constant input to the groundwater box. Nitrate leaching was modelled simply, assuming a fixed proportional retention of deposited $\mathrm{N}$ in catchment soils. The simulation does not therefore consider either short-term climate-related variations in nitrate, or possible long-term catchment "nitrogen saturation" (Stoddard, 1994). Over the stream monitoring period, year-to-year variations in sea-salt deposition were calculated from stream chloride outputs. For the remainder of the simulation, sea-salt deposition was treated as constant.

Finally, the potential influence of climate change on future flow-related acid extremes was assessed using simulations of future runoff for the grid square covering the catchment, generated by the RCAO regional climate model, driven by the Hadley Centre HadAM3H global climate model (Räisänen et al., 2004), and obtained from the PRUDENCE data archive (http://prudence.dmi.dk). Modelled discharge for a 19611990 control period was compared to simulated 2071-2100 discharge under the A2 (medium-high) scenario of the International Panel on Climate Change (IPCC, 2001). This simulation suggests a tendency towards more extreme hydrological conditions, with a dramatic (89\%) decrease in 10th percentile flow and a $24 \%$ decrease in median flow, but increases in high percentile flows (e.g. 18\% increase in 98th percentile flow, $29 \%$ increase in 99 th percentile flow).

\section{Results and discussion}

\subsection{Chemical drivers of acidic extremes}

As described above, "acid" and "non-acid" samples were defined within each of the three periods analysed as those in the lower and upper quartiles of $\mathrm{pH}$ measurements. The $\mathrm{pH}$ data (Table 2) indicate that 10th, 25th and median $\mathrm{pH}$ all increased between the 1980s and 1990s, but that there was little change in 75th or 90th percentiles. No clear change in the distribution of $\mathrm{pH}$ values can be discerned between 1994-1999 and 2000-2004.

For the full set of samples collected during each period, and for all samples in the upper and lower quartiles of $\mathrm{pH}$ during each period, clear changes in major ion chemistry are apparent (Table 3). Observed $\mathrm{SO}_{4}$ concentrations have decreased substantially, under all conditions, consistent with trends observed in surface waters across much of the UK (Davies et al., 2005) and linked to declining S deposition (Cooper, 2005). Mean $\mathrm{NO}_{3}$ was also lower after 1995 than during 1985-1990, despite the absence of a clear overall trend (Fig. 1c). A decrease in Ca is evident in the full dataset and in "non-acid" ( $\mathrm{pH}>75$ th percentile) samples, but there has been no change in the "acid" ( $\mathrm{pH}<25$ th percentile) samples. Overall, the greater reduction in acid anions compared to base cations has led to a clear increase in mean ANC, and to an increase in the ANC of "acid" samples. In the 
Table 3. Chemical composition of streamwater during three time periods, and mean ionic contribution to short-term ANC depression.

\begin{tabular}{|c|c|c|c|c|c|c|c|c|}
\hline & $\mathrm{SO}_{4}$ & $\mathrm{Cl}$ & $\mathrm{NO}_{3}$ & $\mathrm{Ca}$ & $\mathrm{Mg}$ & $\mathrm{Na}$ & $\mathrm{K}$ & ANC \\
\hline \multicolumn{9}{|c|}{ Mean stream chemistry (all data) } \\
\hline 1985-1990 & 73.4 & 157.0 & 10.7 & 43.5 & 55.7 & 144.8 & 2.1 & 5.1 \\
\hline 1994-1999 & 62.3 & 152.2 & 7.5 & 42.7 & 58.8 & 145.0 & 2.8 & 27.3 \\
\hline 2000-2004 & 55.9 & 156.3 & 6.3 & 38.7 & 53.4 & 147.2 & 2.8 & 23.7 \\
\hline \multicolumn{9}{|c|}{ Mean stream chemistry for samples with $\mathrm{pH}<25$ th percentile } \\
\hline 1985-1990 & 72.5 & 171.3 & 16.9 & 35.8 & 54.2 & 149.5 & 3.7 & -17.6 \\
\hline 1994-1999 & 61.8 & 168.3 & 15.7 & 34.2 & 58.3 & 147.5 & 4.4 & -1.4 \\
\hline 2000-2004 & 56.3 & 160.9 & 10.1 & 35.8 & 51.9 & 143.5 & 4.0 & 7.9 \\
\hline \multicolumn{9}{|c|}{ Mean stream chemistry for samples with $\mathrm{pH}>75$ th percentile } \\
\hline 1985-1990 & 69.2 & 150.6 & 2.7 & 52.6 & 56.7 & 144.5 & 1.3 & 32.7 \\
\hline 1994-1999 & 60.0 & 145.7 & 1.7 & 50.9 & 60.6 & 140.4 & 2.1 & 46.5 \\
\hline 2000-2004 & 55.0 & 146.5 & 1.6 & 43.8 & 55.2 & 139.7 & 2.1 & 37.6 \\
\hline \multicolumn{9}{|c|}{ Mean change in concentrations between high- and low-pH samples } \\
\hline & $\Delta \mathrm{SO}_{4}$ & $\Delta \mathrm{Cl}$ & $\Delta \mathrm{NO}_{3}$ & $\Delta \mathrm{Ca}$ & $\Delta \mathrm{Mg}$ & $\Delta \mathrm{Na}$ & $\Delta \mathrm{K}$ & $\triangle \mathrm{ANC}$ \\
\hline 1985-1990 & 3.3 & 20.8 & 14.2 & -16.8 & -2.5 & 5.0 & 2.4 & -50.3 \\
\hline 1994-1999 & 1.8 & 22.6 & 14.0 & -16.7 & -2.2 & 7.0 & 2.4 & -47.8 \\
\hline 2000-2004 & 1.2 & 14.4 & 8.5 & -8.1 & -3.3 & 3.8 & 2.0 & -29.8 \\
\hline \multicolumn{9}{|c|}{ Mean contribution of each ion to reduction in ANC (\%) } \\
\hline & $\mathrm{dSO}_{4}$ & $\mathrm{dCl}$ & $\mathrm{dNO}_{3}$ & $\mathrm{dCa}$ & $\mathrm{dMg}$ & $\mathrm{dNa}$ & $\mathrm{dK}$ & \\
\hline 1985-1990 & $7 \%$ & $41 \%$ & $28 \%$ & $33 \%$ & $5 \%$ & $-10 \%$ & $-5 \%$ & \\
\hline 1994-1999 & $4 \%$ & $47 \%$ & $29 \%$ & $35 \%$ & $5 \%$ & $-15 \%$ & $-5 \%$ & \\
\hline 2000-2004 & $4 \%$ & $48 \%$ & $29 \%$ & $27 \%$ & $11 \%$ & $-13 \%$ & $-7 \%$ & \\
\hline
\end{tabular}

"non-acid" samples, the reduction in base cations has kept pace with that in acid anions, and ANC appears to be little changed. As a consequence, the average ANC reduction ( $\triangle \mathrm{ANC}$ ) between "non-acid" and "acid" samples has decreased from $50 \mu \mathrm{eq} 1^{-1}$ in $1985-1990$ to $30 \mu \mathrm{eq}^{-1}$ in 2000-2004. The small apparent increase in the ANC of "acid" samples between 1994-1999 and 2000-2004 is noteworthy in that it occurred during a period when lower quartile $\mathrm{pH}$ remained static. An explanation for this appears to be the increase in DOC which has occurred at the Gwy (Fig. 1), as in many other UK surface waters (Evans et al., 2005; Worrall et al., 2004). Increased organic acid concentrations will suppress stream $\mathrm{pH}$, but will not affect charge balance ANC.

The changes in ion concentration occurring between high$\mathrm{pH}$ and low-pH samples $(\Delta \mathrm{X})$ and their proportional contributions to the reduction in ANC ( $\mathrm{dX})$ are shown in Table 3 and Fig. 2. As in some other areas where similar methods have been applied (e.g. Evans et al., 1995; Wigington et al., 1996), this analysis suggests that, while long-term elevated mean $\mathrm{SO}_{4}$ concentrations are the dominant cause of chronic acidification at the stream, short-term variability in $\mathrm{SO}_{4}$ (between high- and low-pH conditions) is typically quite small. Therefore, variations in ions other than $\mathrm{SO}_{4}$ must account for most of the short-term variation in ANC. In contrast to $\mathrm{SO}_{4}$, the other main pollutant anion, $\mathrm{NO}_{3}$, contributes sig-

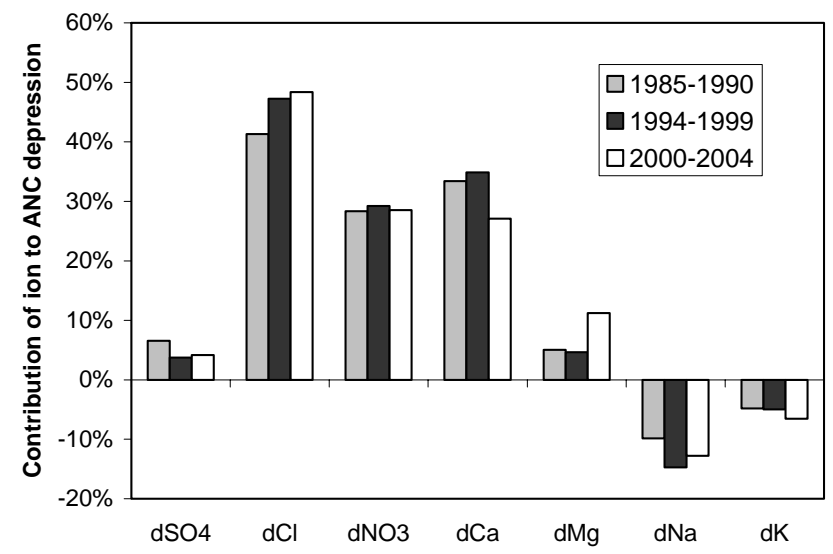

Fig. 2. Average contribution of changes in individual ions to shortterm reductions in ANC during three intensively sampled periods.

nificantly (around 30\%) to short-term ANC depression. The role of $\mathrm{NO}_{3}$ is discussed further below. $\mathrm{Cl}$ increases also appear to be important contributors to short-term ANC reduction, although they must be considered in the context of neutral sea-salt additions, together with additions of base cations. The major marine cation, $\mathrm{Na}$, does show a positive change between high-pH and low-pH samples, but this 

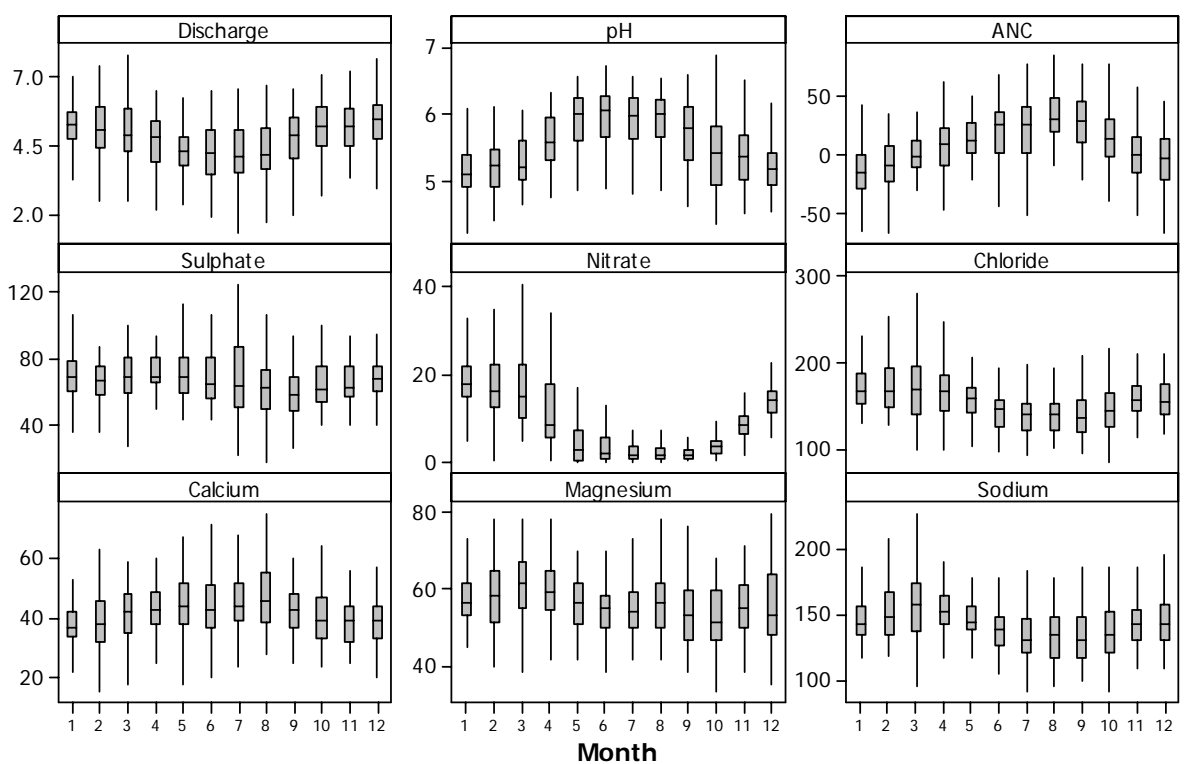

Fig. 3. Monthly box and whisker plots for stream discharge (natural log of discharge in $1 \mathrm{~s}^{-1}$ ), $\mathrm{pH}$ (pH units), Acid Neutralising Capacity and major ions (all eq $1^{-1}$ ). For each month, central line represents median, boxes 25 th and 75 th percentiles, and whiskers 10 th and 90 th percentiles. Months numbered from January to December.

is only sufficient to offset around a quarter of the $\mathrm{Cl}$ increase; this represents the buffering of $\mathrm{Na}$ variation by soil cation exchange: the sea-salt effect. Ignoring any equivalent changes in $\mathrm{Mg}$ (which are difficult to isolate due to this cation also having a significant catchment source), the sea-salt effect defined as dCl-dNa can on average account for around a third of short-term ANC depression.

$\mathrm{Ca}$ is primarily catchment-derived, and concentrations are typically higher in deep baseflow than near-surface throughflow. Ca dilution therefore makes a significant contribution to ANC depression, and is strongly flow-related (although should be noted that the greater proportional increase in discharge, relative to the concentration decrease, means that maximum flux of $\mathrm{Ca}$, and other ions, occurs at peak flows). For $\mathrm{Mg}$, which has both marine and catchment sources, short-term behaviour is intermediate between (catchmentderived) $\mathrm{Ca}$ and (marine-derived) $\mathrm{Na}$; on average, a small $\mathrm{Mg}$ decrease makes a minor contribution to ANC depressions. K, by contrast, is strongly influenced by biological cycling, and tends to peak during winter high flows, thus having a minor ameliorating influence on ANC depression.

Comparing the three periods for which this analysis has been undertaken, there has been remarkably little variation in the relative importance of the different ionic drivers of short-term ANC reduction. The three major drivers appear to be $\mathrm{NO}_{3}$ increases, the sea-salt effect and $\mathrm{Ca}$ dilution, with each on average contributing approximately a third of the observed ANC reduction during all periods. In absolute terms, the reduced magnitude of $\triangle \mathrm{ANC}$ has therefore occurred because $\Delta \mathrm{NO}_{3}, \Delta \mathrm{Cl}$ and $\Delta \mathrm{Ca}$ have all decreased in approxi- mately the same proportion. The reduced magnitude of $\mathrm{NO}_{3}$ peaks may reflect a reduced deposition $\mathrm{N}$ loading, and decreased Ca dilution may be explicable in terms of reduced base cation leaching from the soil under low and intermediate flow conditions by mobile $\mathrm{SO}_{4}$ and $\mathrm{NO}_{3}$ anions (Reuss et al., 1987). The reduction in $\Delta \mathrm{Cl}$ is more surprising, since seasalt deposition is independent of pollutant deposition, and may be a consequence of climatic fluctuations during the monitoring period. The sea-salt effect may be expected to continue to cause short-term displacement of $\mathrm{H}$ and $\mathrm{Al}$ from the soil to the stream as long as soil base saturation remains depleted. Although sea-salts are themselves a source of base cations to the soil, MAGIC model simulations for the site (Evans, 2005) indicate that soil recovery may take decades or even centuries, and therefore that sea-salt episodes are likely to continue to occur during this time. In this case, if other episode drivers continue to decline, the sea-salt effect may become a proportionally more important cause of ANC reductions, and the small recorded rise in $\mathrm{dCl}-\mathrm{dNa}(31 \%$ in $1983-1990$, 32\% in $1994-1999,35 \%$ in 2000-2004) might become more pronounced in future.

The method employed here was selected to be applicable to long time series with a moderate sampling frequency; a limitation of this approach is that, by lumping all high- and low-pH samples for a given time period together, it does not distinguish the relative importance of seasonal versus episodic changes within this period. Seasonal box plots for the full monitoring dataset (Fig. 3) indicate that a significant part of the overall variation is due to seasonality, with the lowest $\mathrm{pH}$ and $\mathrm{ANC}$ occurring during winter months. $\mathrm{NO}_{3}$ 


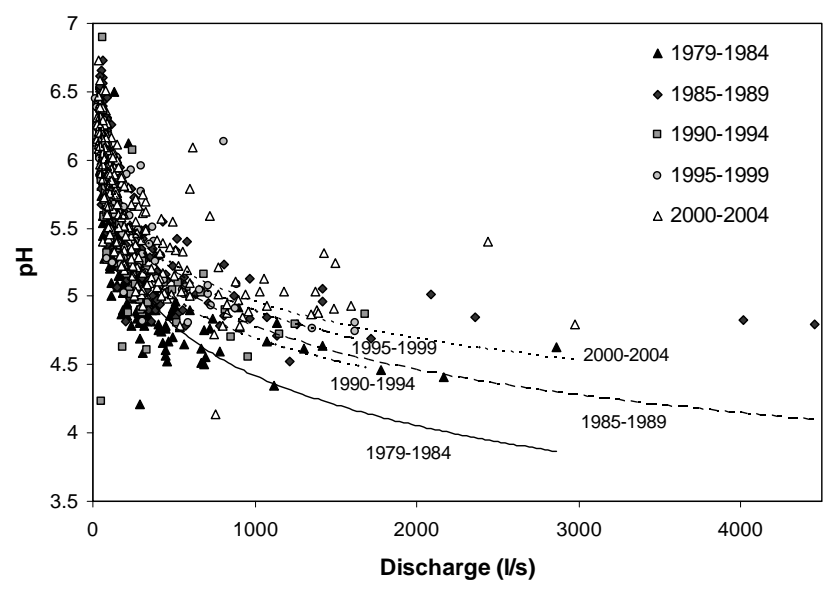

Fig. 4. Stream $\mathrm{pH}$ versus mean discharge on the day of sampling, for five approximately equal time intervals. Lines show logarithmic least squares regression fit for $\mathrm{pH}$ versus flow for each time interval.

and $\mathrm{Cl}$ both peak at this time, and have a clear seasonal cycle, although in both cases there is considerable withinmonth variation during periods of high concentration. $\mathrm{Ca}$ is less seasonal, with a higher degree of within-month variability. Overall, both ANC and $\mathrm{pH}$ may fall to low levels (e.g. $\mathrm{ANC}<0, \mathrm{pH}<5$ ) at any time of the year, but the majority of samples in the lower quartile of $\mathrm{pH}(77-84 \%$ per period analysed) were collected between October and March, while most upper-quartile samples (80-86\%) were collected between April and September. Although this suggests that much of the variation in ANC analysed may be seasonal rather than episodic, it is worth noting that discharge is itself highly seasonal, with $73 \%$ of upper-quartile flows occurring during the winter period. Sea-salt episodes are also associated with winter storms. Effectively, acid episodes can be considered as superimposed on an underlying seasonal cycle, in which both the most acidic mean conditions, and the most severe episodic ANC and $\mathrm{pH}$ depressions below this mean, occur during winter.

\subsection{Temporal changes in episode severity}

There is a strong relationship between stream $\mathrm{pH}$ and discharge (Fig. 4). The relationship is described by logarithmic regression fits for all five-year periods (Fig. 4; Table 4). The weakest relationship (1990-1994) coincided with both the smallest number of samples (Table 1), and a peak in sea-salt deposition which might be expected to confound the relationship between $\mathrm{pH}$ and discharge. The analysis does not take explicit account of seasonal influences on $\mathrm{pH}$, which may explain some of the scatter in the regression relationships. However, much of the seasonal variation in $\mathrm{pH}$ is likely to be linked to seasonal variation in discharge, and thus implicit within the regression relationships.
Table 4. Logarithmic regression fits between $\mathrm{pH}$ and stream discharge $\left(\mathrm{Q}\right.$, in $\left.1 \mathrm{~s}^{-1}\right)$ during five time periods.

\begin{tabular}{cclcc}
\hline Time interval & Samples & Regression equation & $\mathrm{R}^{2}$ & $\mathrm{p}$ \\
\hline $1979-1984$ & 191 & $\mathrm{pH}=8.07-0.529 \mathrm{Ln}(\mathrm{Q})$ & 0.78 & $<0.001$ \\
$1985-1989$ & 243 & $\mathrm{pH}=7.95-0.458 \mathrm{Ln}(\mathrm{Q})$ & 0.72 & $<0.001$ \\
$1990-1994$ & 69 & $\mathrm{pH}=7.55-0.414 \mathrm{Ln}(\mathrm{Q})$ & 0.56 & $<0.001$ \\
$1995-1999$ & 107 & $\mathrm{pH}=7.81-0.423 \mathrm{Ln}(\mathrm{Q})$ & 0.74 & $<0.001$ \\
$2000-2004$ & 244 & $\mathrm{pH}=7.65-0.389 \mathrm{Ln}(\mathrm{Q})$ & 0.73 & $<0.001$ \\
\hline
\end{tabular}

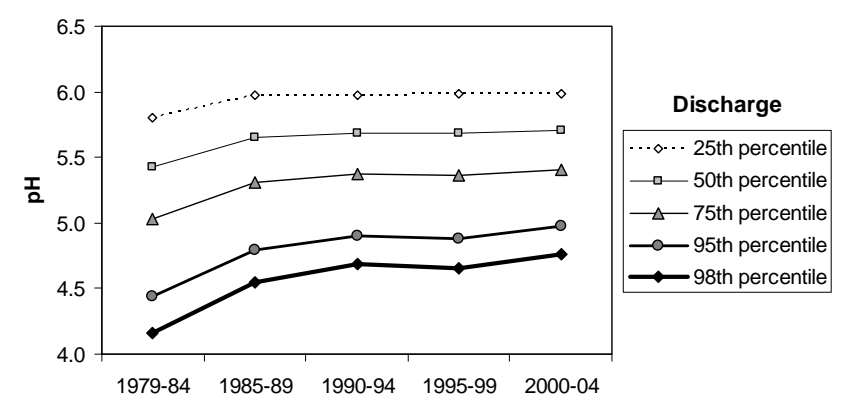

Fig. 5. Temporal changes in stream $\mathrm{pH}$ under a range of range of flow conditions. Discharge percentiles are derived from the full daily flow record, 1979-2004. pH estimates are based on the regression equations in Table 4.

Overall, pH-discharge relationships appear strong, and there appears to have been a change in the relationship over time; over the 25 year period, the intercept of the regression has remained fairly stable in the range 7.5-8.1, but the slope coefficient has decreased progressively over time (Table 4). A plot of $\mathrm{pH}$ predicted by these equations for a range of percentile flows (Fig. 5) illustrates the effect of the changing relationship over time; at low flows, there has been relatively little change, whilst at moderate to high flows there has on average been a substantial and sustained $\mathrm{pH}$ increase. In terms of water flowpath, this suggests that the shallow soils supplying high flows are recovering more rapidly from acidification than deeper baseflow sources. Conceptually this can be considered the reversal of a historic pattern of acidification in which poorly-buffered shallow soils acidified more rapidly, and to a greater extent, than deeper soils with greater buffering from mineral weathering. The implication of this finding is that, at the Afon Gwy, long-term reductions in acid deposition over the monitoring period have led to a reduction in the magnitude of acid episodes. It is also worth noting that the largest apparent pH recovery, between 1979-1984 and 1985-1989, coincided with the period of greatest reductions in sulphur deposition at UK monitoring sites such as Eskdalemuir (Hayman et al., 2000). 

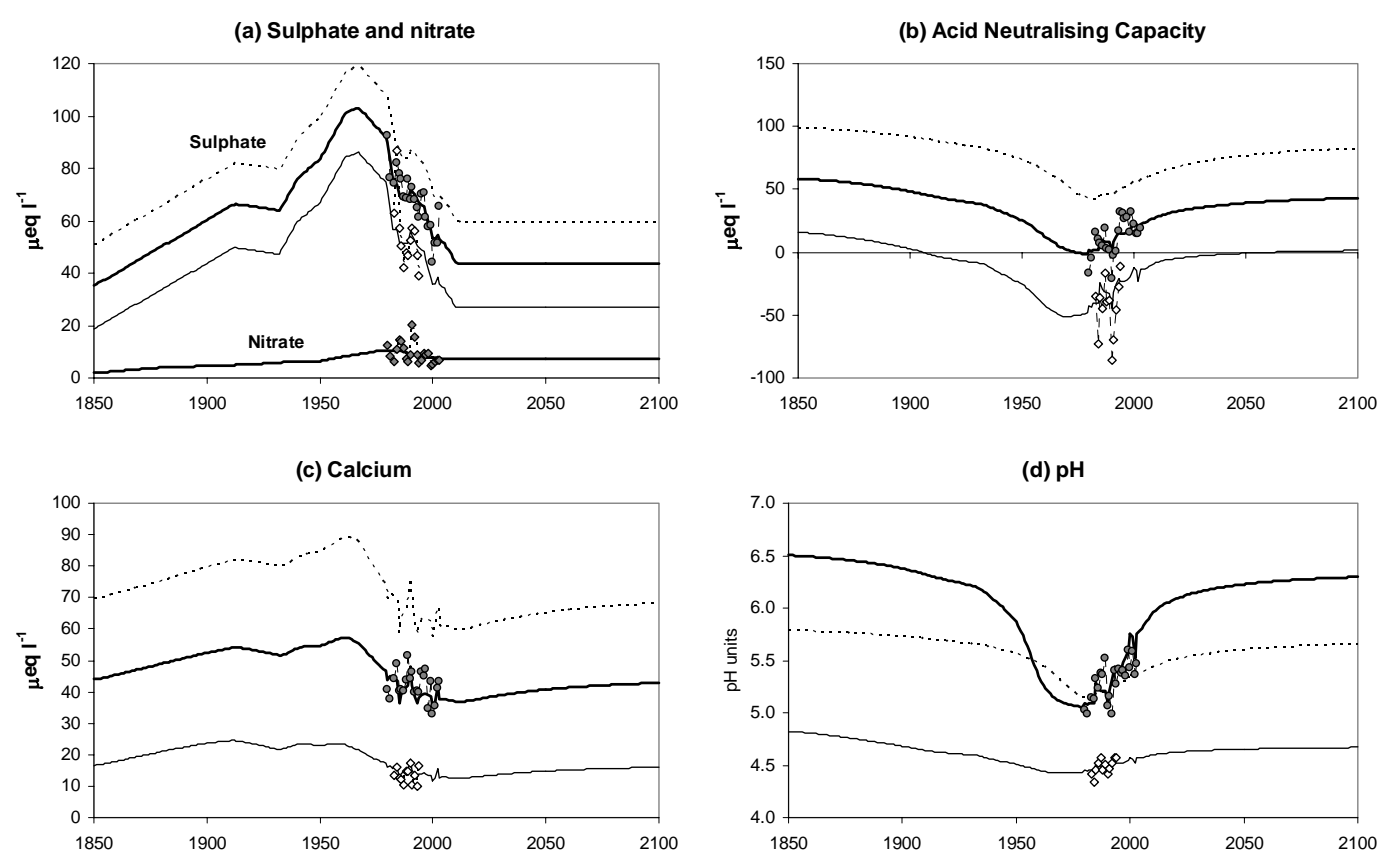

(e) Magnesium
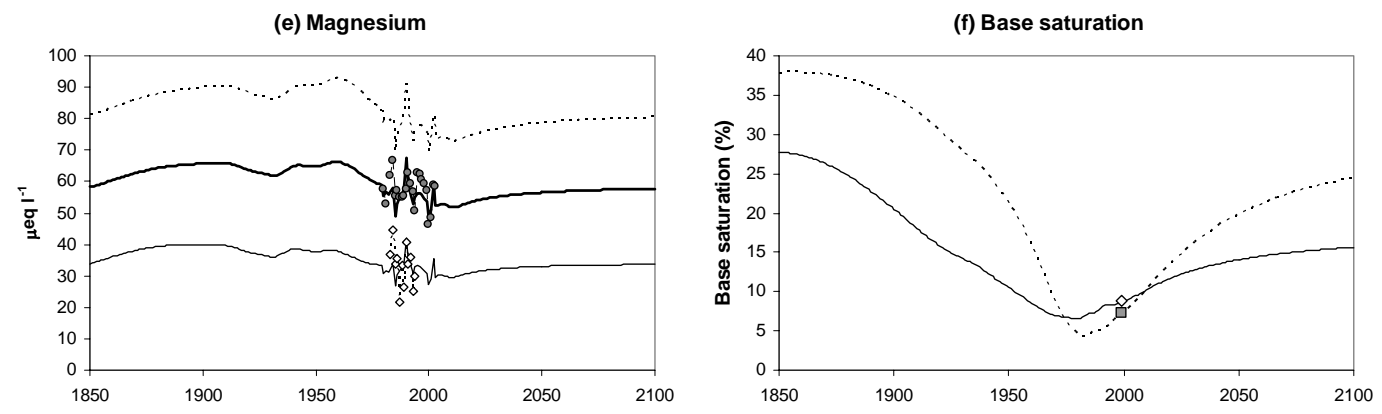

Fig. 6. MAGIC-simulated long-term changes in annual mean chemistry of streamwater (thick line), shallow soilwater (thin line) and groundwater (dashed line). Filled circles represent annual mean observed stream chemistry, open diamonds represent annual mean observed B horizon (i.e. upper soil box) chemistry. Lines on base saturation plot (f) represent modelled upper box (thin line) and lower box (dashed line) soil chemistry, open diamond and filled square represent 1999 observed values for the same horizons.

\subsection{Modelling future acidic extremes}

The two-box, yearly time-step calibration of MAGIC provides a generally good fit to observed changes in annual mean stream chemistry, and to the (shorter) record of soil solution chemistry (Fig. 6). The assumption that $\mathrm{SO}_{4}$ outputs are approximately equal to (deposition plus weathering) inputs on an annual basis is supported by a generally close fit between the time series of simulated and observed stream $\mathrm{SO}_{4}$ concentrations. Deviations from the simulated line can be linked to unmodelled episodic $\mathrm{SO}_{4}$ flushes during drought years (discussed below). Simulations of base cations, ANC and $\mathrm{pH}$ capture the trend, and some of the short-term variability (associated mainly with variable sea-salt deposition) of the observed record. Two periods of pronounced ANC depression in the shallow soil water are not captured; these apparently correspond to a post-drought $\mathrm{SO}_{4}$ flush (1984) and a period of elevated sea-salt deposition (1990-1991). Interannual climate-related variations in $\mathrm{NO}_{3}$ were not modelled, and were not therefore captured by the MAGIC simulation.

Overall, the two-box MAGIC calibration for the current study provides a largely consistent simulation with the variable sea-salt, one-box calibration described in Evans (2005). This suggests that including separate upper soilwater and groundwater boxes in the model does not substantially change the simulation of annual mean stream chemistry by the model. However, by simulating the chemistry of the separate soil water and groundwater "end members" that generate streamflow, some inferences may be drawn regarding the likely short-term variability of stream chemistry due to hydrological variations. The differences between soil water and groundwater $\mathrm{SO}_{4}$ are solely due to the specified weathering input of $\mathrm{SO}_{4}$ to groundwater. Higher base cation concentrations and ANC in groundwater also reflect a 
Table 5. Average MAGIC modelled ANC in soilwater and groundwater, and the difference between them (ANC range) for an illustrative set of 5-year periods.

\begin{tabular}{rrrr}
\hline Time period & $\mathrm{ANC}_{\text {soilwater }}$ & $\mathrm{ANC}_{\text {groundwater }}$ & ANC range \\
\hline $1850-1855$ & 15.6 & 98.4 & 82.9 \\
$1900-1950$ & 1.5 & 90.7 & 89.3 \\
$1960-1965$ & -45.5 & 61.8 & 107.3 \\
$1979-1984$ & -40.1 & 42.4 & 82.4 \\
$1985-1989$ & -30.3 & 45.5 & 75.8 \\
$1990-1994$ & -28.9 & 47.3 & 76.2 \\
$1995-1999$ & -21.4 & 52.2 & 73.6 \\
$2000-2004$ & -15.5 & 56.2 & 71.7 \\
$2005-2010$ & -10.7 & 60.1 & 70.8 \\
$2015-2020$ & -5.3 & 66.5 & 71.9 \\
$2045-2050$ & -0.9 & 76.2 & 77.1 \\
$2095-2100$ & 1.3 & 82.0 & 80.7 \\
\hline
\end{tabular}

higher (calibrated) base cation weathering input from deeper soils and fractured bedrock, and are consistent with the general importance of base cation dilution as a driver of acid episodes. Note that, although $\mathrm{pH}$ is also lower in soil water, streamwater does not represent a conservative mix of endmembers due to changes in organic acid concentration, $\mathrm{Al}$ solubility and dissolved $\mathrm{CO}_{2}$ between soil and stream. All retention of $\mathrm{NO}_{3}$ was assumed to occur in the biologically active upper soil, so modelled concentrations do not vary with depth.

The range between modelled soil and groundwater endmembers provides an indication of the likely variations in the magnitude of acid episodes over time, since the most acid conditions during high flow may be expected when soil water is dominant, and the most alkaline low-flow conditions when groundwater is dominant. An important caveat to this, however, is that the model simulates annual mean end-member concentrations. Thus, the model does not take account of seasonal variations in end-member composition, which would be expected to extend the overall range of conditions (and therefore episodic $\mathrm{pH}$ and ANC depressions) in both soil water and streamwater. However, it seems reasonable to expect that the maximum magnitude of episodic chemistry change within a year will be correlated to the difference between the mean annual composition of the two endmembers. The mean value of $\mathrm{ANC}_{\text {groundwater }}-\mathrm{ANC}_{\text {soilwater }}$ during different time periods (Table 5) provides some support for this assumption, showing a decline between 19791984 and 2000-2004, consistent with the reduction in flowrelated episode magnitude over the same period indicated by the analysis of pH-discharge relationships (Fig. 4). In the hindcast simulation, the model also suggests that episode magnitude rose from the pre-industrial period to a maximum at the time of peak S deposition in the 1960s; this reflects the greater acidification, and subsequent recovery, of upper soils

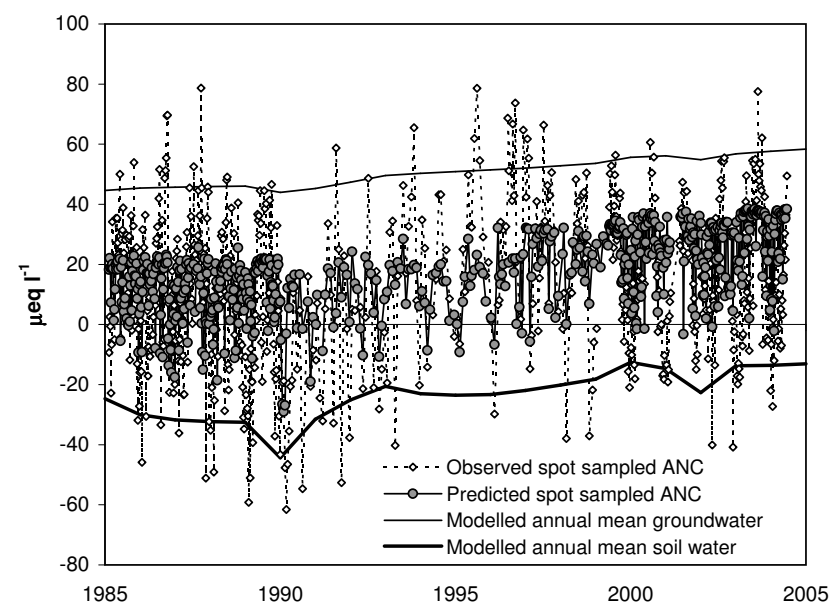

Fig. 7. Spot sampled ANC, and instantaneous predicted ANC estimated as a mixture of soilwater (thick line) and groundwater (thin line) end-members, from 1985 to 2004 . End-member proportions are defined from discharge according to Eq. (4).

relative to the deeper, more buffered material supplying baseflow. However, after the stabilisation of deposition in 2010 (according to the scenario used), ANC continues to increase in the groundwater end-member, but stabilises at around zero in the upper soil end-member (Fig. 6). As a result, the separation between groundwater and soilwater ANC is predicted to increase (Table 5), suggesting that episode magnitude may once again increase in the future.

An attempt was made to simulate the variation in ANC with flow, by applying an equation derived by Neal et al. (1992) for the Afon Gwy, to estimate the proportion of soilwater and groundwater supplying streamflow at a given discharge (in $1 \mathrm{~s}^{-1}$ ):

Proportion of soilwater $=0.839\left(1-0.692 e^{-0.0023 \times \text { discharge }}\right)(4)$

Equation (4) was applied to recorded daily mean discharge coincident with all spot-samples collected from 1985 (following the change in $\mathrm{SO}_{4}$ analytical method) until 2004, and compared to measured ANC. According to Eq. (4), neither end member ever completely dominates runoff; the soilwater contribution can never fall below $26 \%$, and at the highest recorded discharge it provided $84 \%$ of runoff. The results (Fig. 7) show that, although the combined MAGIC and end-member mixing models often predict the timing of acid episodes, and the overall increase in ANC minima over the monitoring period, they underpredict the overall range of short-term ANC variation. Several factors may account for this. Firstly, MAGIC was only applied at an annual timestep; a monthly time-step would allow for seasonal variations in end-member composition that would expand the overall ANC range. Secondly, the mixing model only reproduces ANC changes related to discharge (primarily base cation dilution). Additional episodic changes associated with 


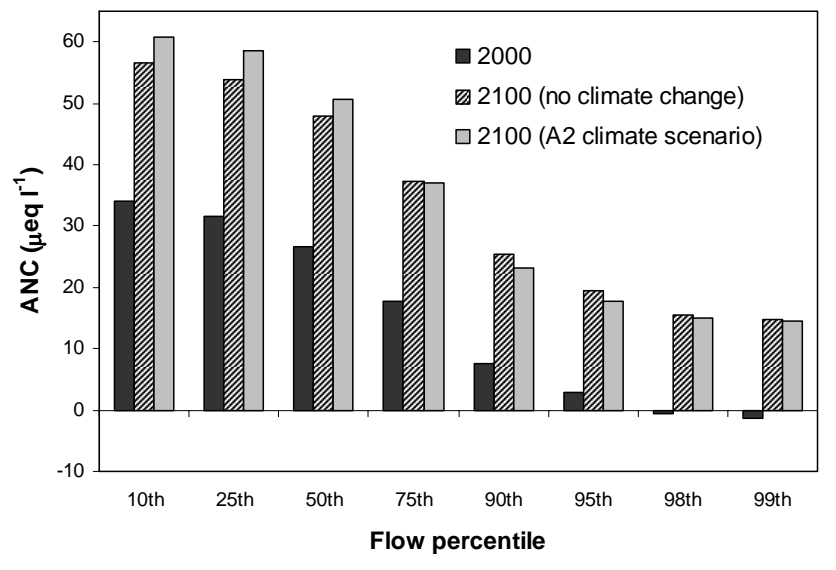

Fig. 8. ANC for a range of flow percentiles, calculated from the two-box MAGIC application and Eq. (4), for 2000, and for 2100 according to current deposition forecasts with (a) present-day discharge regime, and (b) altered discharge regime predicted by the HadAM3H/RCAO global/regional climate models, under the IPCC A2 climate change scenario.

$\mathrm{NO}_{3}$ or $\mathrm{SO}_{4}$ peaks, or short-term sea-salt episodes, are omitted. A more sophisticated, shorter-timestep model application incorporating these mechanisms might provide an improved simulation of ANC extremes, but was beyond the scope of this study. Thirdly, since there is a better correspondence between MAGIC end-member chemistry and observed ANC extremes than the predictions obtained from Eq. (4), it may be that this equation underpredicts the extent to which groundwater and soil water dominate runoff at low and high flow respectively. Finally, the two end-member model is inevitably a simplification of the full range of water sources that contribute to runoff, notably in lumping all flow derived from below the B horizon as "groundwater" of uniform composition. Deep borehole measurements from nearby (e.g. Neal et al., 2004) suggest that deeper groundwater, although providing only a small absolute contribution to streamflow, is substantially more alkaline, and likely to provide a significant proportion of discharge under extreme baseflow conditions. This may account for the under-prediction of ANC maxima by the combined MAGIC and end-member models. In terms of predicting the biological consequences of short-term chemical variation, however, simulation of ANC maxima is less important than accurate prediction of ANC minima.

4.4 Potential effects of climate change on future acid extremes

According to the climate change models and scenario used, there is predicted to be an increased occurrence of both low flow and high flow extremes at the Afon Gwy. To estimate the potential impact of altered flow regime on stream ANC, Eq. (4) was applied to a range of discharge percentiles

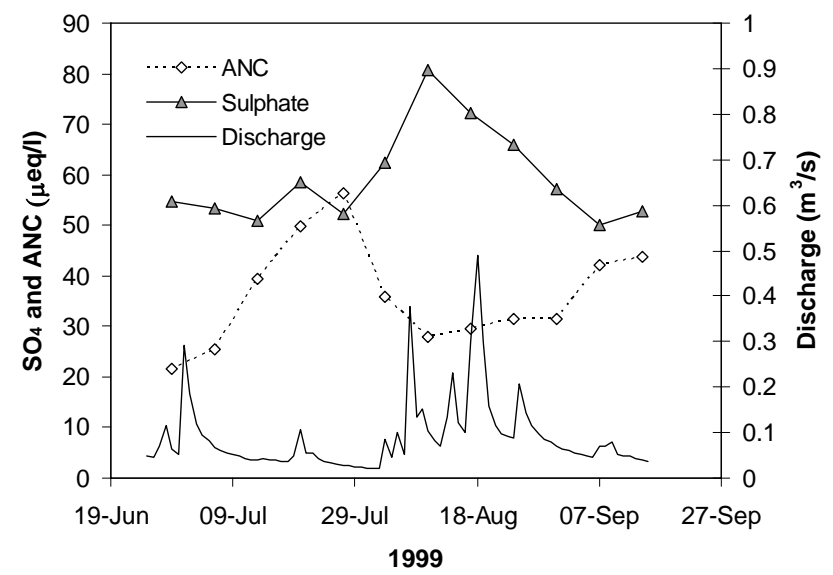

Fig. 9. Example of a post-drought sulphate flush episode during 1999.

for 2000, with the present-day observed flow regime and MAGIC-modelled end-member chemistry, and for 2100 with MAGIC forecast end-member chemistry with 1) present-day flow regime, and 2) forecast changes in flow regime. The results (Fig. 8) clearly suggest that the effects of changing endmember composition (driven by deposition reductions) will greatly exceed the effects of changing discharge regime at all flows. At high flow, in particular, the detrimental impact of increased high flow extremes appears negligible. Given the large predicted increase in peak flows this seems surprising, and occurs due to the relatively low sensitivity of the soilwater proportion predicted by Eq. (4) at higher discharges. It must be emphasised, given the fairly poor fit between modelled and observed instantaneous ANC values during the monitoring period (Fig. 7), that these predictions may underestimate the actual effect of increased peak discharges on ANC. However, relative stability of observed stream $\mathrm{pH}$ at higher flows during the monitoring period (Fig. 4) provides some support to the conclusion that increased extreme discharges may have a relatively minor impact on episode severity.

Although these results suggest that the severity of discharge-driven (i.e. dilution) episodes is not strongly sensitive to predicted climate change, this is unlikely to be the case for all mechanisms that cause acid episodes at the site. In particular, there is a risk of increased severity of sea-salt episodes, since the westerly winter storm events associated with sea-salt deposition in northwest Europe are predicted to increase in magnitude and severity in future (Hulme et al., 2002). Elevated sea-salt deposition would add base cations to the soil, but increase displacement of acidity to streamwaters. Although sea-salt deposition might accelerate recovery in soil base saturation, this recovery is nevertheless likely to take decades or even centuries in acidified, poorly buffered soils such as those at the Gwy (Skeffington and Brown, 1992; 
Reynolds, 1997), and sea-salt episodes are likely to continue until soil base status recovers towards pre-acidification levels (Evans, 2005).

In addition, despite $\mathrm{SO}_{4}$ increases being shown to be a minor cause of ANC decreases for the dataset as a whole, there is clear evidence that infrequent $\mathrm{SO}_{4}$ flushes do lead to significant acid episodes. Figure 9 shows an example of a small $\mathrm{SO}_{4}$ flush event, which led to a clear decrease in ANC, whilst a larger $\mathrm{SO}_{4}$ peak, extending over several months, is evident in the full time series during 1995-1996 (Fig. 1c). As in some other studied sites (Dillon et al., 1997; Adamson et al., 2001), $\mathrm{SO}_{4}$ flushes occur infrequently at the site, following drought periods. As such they have a minor influence on the calculation of average drivers of ANC depression, and (because the flush occurs during the first, often small, hydrological event after the drought) are not tightly correlated with discharge. In a companion study of episodic processes at the Birkenes catchment in Norway, Wright (2008) demonstrates a correlation between the magnitude of $\mathrm{SO}_{4}$ pulses and the number of antecedent days below a threshold discharge. The climate-change runoff scenario for the Gwy, as well as predicting an increase in high-flow discharges, also predicts a large increase in the number of days with low flows (reflected in a $65 \%$ reduction in 25 th percentile discharge). If this were to occur, $\mathrm{SO}_{4}$ flushes could become more an important driver of acid episodes in future. However the effect of climate change might be offset by a gradual depletion of soil $\mathrm{S}$ stores, in line with the continued reduction in $\mathrm{S}$ deposition (Wright, 2008).

Of the other drivers of acid episodes considered, $\mathrm{NO}_{3}$ may be particularly sensitive to changes in climate due to the strong biological control on $\mathrm{N}$ cycling. At the Gwy, $\mathrm{NO}_{3}$ pulses are associated with winter soil freezing events (Monteith et al., 2000), and rising winter temperatures due to climate change could therefore reduce the magnitude or frequency of $\mathrm{NO}_{3}$ peaks. In catchments where soil freezing events are caused by reduced snowpack accumulation, however, the consequences of climate change may be very different. In addition, progressive $\mathrm{N}$-saturation of catchment soils by continued high $\mathrm{N}$ deposition could affect both mean $\mathrm{NO}_{3}$ concentrations, and its seasonal and episodic pattern, even in the absence of climatic changes (Stoddard, 1994). Finally, the future behaviour of DOC, and associated organic acids, remains a major uncertainty in the prediction of stream chemistry. Organic acids have not been considered fully in this study, since they do not form part of the calculation of charge balance ANC, but their effect on $\mathrm{pH}$ (and on aquatic biota) may be considerable; increases in DOC at the Gwy are thought to explain the less dramatic rise in $\mathrm{pH}$ when compared to ANC in recent years (e.g. Fig. 1). Recent evidence suggest that much of the rising DOC trend may be linked to recovery from acidification (Evans et al., 2006), although climatic factors undoubtedly also influence DOC variations. Due to continuing uncertainty in the relative importance of different climatic and non-climatic factors, it is difficult to predict the future influence of organic acids on stream acidity. However a MAGIC application at the Gwy incorporating rising annual mean organic acid concentrations (Evans, 2005) did suggest a potentially significant impact.

\section{Summary and conclusions}

The analysis presented suggests that several biogeochemical processes contribute to acid extremes, either individually or in combination. All are in some way linked to climatic drivers, and may therefore be affected by climate change. At the Gwy, the dominant climatic influence on acidity appears to be through hydrology, with a strong relationship between $\mathrm{pH}$ and discharge. Analysis of changes in this relationship over time suggest that, as catchment soils have recovered from acidification, $\mathrm{pH}$ minima have increased more rapidly than mean $\mathrm{pH}$. Thus, reductions in acid deposition have reduced the magnitude of episodes. However predictions using MAGIC suggest that, although both mean and minimum ANC will continue to rise, future improvements in minimum ANC will be less than those in mean ANC, leading to an increase in episode magnitude beyond 2010. Although climate change forecasts suggest an increase in discharge maxima in future, the model applied suggests that the impact of this on acidic extremes will be relatively minor. However, several other mechanisms by which projected changes in climate could detrimentally affect acid episodes are identified, notably an increase in the severity of acid episodes due to elevated winter sea-salt deposition, and enhanced sulphatedriven episodes following intensified summer droughts. Differences in the main episodic drivers at the Gwy and at the Birkenes catchment in Norway (Wright, 2008) demonstrate that these results should not be considered applicable to all acid-sensitive streams, and a more wide-ranging assessment of the drivers of chemical extremes will be required to provide generalised conclusions regarding the implications of climate change for such systems.

Acknowledgements. This study was supported by the European Union Framework Programme 6 Eurolimpacs project (GOCECT-2003-505540). The stream monitoring data used result from the hard work and determination of many people over twenty-five years. Climate forecasts were provided through the PRUDENCE data archive, funded by the EU through contract EVK2-CT-2001-00132. We are grateful to the reviewers, to J. Cosby for MAGIC assistance, and to A. Wade for helping to correct the considerable failings of an earlier version of the manuscript.

Edited by: P. Dillon and R. F. Wright

\section{References}

Adamson, J. K., Scott, W. A., Rowland, A. P., and Beard, G. R.: Ionic concentrations in a blanket peat bog in northern England and correlations with deposition and climate variables, Eur. J. Soil Sci., 52, 69-79, 2001. 
Baker, J. P., Bernard, D. P., Christensen, S. W., and Sale, M. L.: Biological effects of changes in surface water acid-base chemistry. National Acid Precipitation Assessment Program, Washington, D.C., State of Sci/Technol Rep. No. 9, 1990.

Baker, J. P., VanSickle, J., Gagen, C. J., DeWalle, D. R., Sharpe, W. E., Carline, R. F., Baldigo, B. P., Murdoch, P. S., Bath, D. W., Kretser, W. A., Simonin, H. A., and Wigington, P. J.: Episodic acidification of small streams in the northeastern United States: Effects on fish populations, Ecol. Appl., 6, 422-437, 1996.

Bayley, S. E., Behr, R. S., and Kelly, C. A.: Retention and release of $\mathrm{S}$ from a freshwater wetland, Water Air Soil Pollut., 31, 101-114, 1986.

Boorman, D. B., Hollis, J. M., and Lilly, A.: Hydrology of Soil Types: A hydrologically-based classification of the soils of the United Kingdom, Institute of Hydrology, Report 126, Wallingford, UK, 137 pp, 1995.

Bottrell, S., Coulson, J., Spence, M., Roworth, P., Novak, M., and Forbes, L.: Impacts of pollutant loading, climate variability and site management on the surface water quality of a lowland raised bog, Thorne Moors, E. England, UK, Appl. Geochem., 19, 413422, 2004

Carline, R. F., DeWalle, D. R., Sharpe, W. E., Dempsey, B. A., Gagen, C. J., and Swistock, B.: Water chemistry and fish community responses to episodic stream acidification in Pennsylvania, USA, Environ. Pollut., 78, 45-48, 1992.

Chapman, P. J., Reynolds, B., and Wheater, H. S.: Hydrochemical changes along stormflow pathways in a small moorland headwater catchment in Mid-Wales, UK, J. Hydrol., 116, 210-215, 1993.

Clair, T. A., Ehrman, J. M., and Higuchi, K.: Changes in freshwater carbon exports from Canadian terrestrial basins to lakes and estuaries under a $2 \times \mathrm{CO}_{2}$ atmospheric scenario, Global Biogeochem. Cy., 13, 1091-1097, 1999.

Cooper, D. M.: Evidence of sulphur and nitrogen deposition signals at the United Kingdom Acid Waters Monitoring Network sites, Environ. Pollut., 137, 41-54, 2005.

Cosby, B. J., Ferrier, R. C., Jenkins, A., and Wright, R. F.: Modelling the effects of acid deposition: refinements, adjustments and inclusion of nitrogen dynamics in the MAGIC model, Hydrol. Earth Syst. Sci., 5, 499-517, 2001, http://www.hydrol-earth-syst-sci.net/5/499/2001/.

Davies, T. D., Tranter, M., Wigington, P. J., and Eshleman, K. N.: 'Acidic episodes' in surface waters in Europe, J. Hydrol., 132, 25-69, 1992.

Davies, J. J. L., Jenkins, A., Monteith, D. T., Evans, C. D., and Cooper, D. M.: Trends in surface water chemistry of acidified UK Freshwaters, 1988-2002, Environ. Pollut., 137, 27-40, 2005.

DeWalle, D. R. and Swistock, B. R.: Causes of episodic acidificationin five Pennsylvania streams on the northern Appalachian Plateau, Water Resour. Res., 30, 1955-1963, 1994.

Dillon, P. J., Molot, L. A., and Futter, M.: The effect of El Ninorelated drought on the recovery of acidified lakes, Environ. Monitor. Assessment, 46, 105-111, 1997.

Evans, C. D.: Modelling the effects of climate change on an acidic upland stream, Biogeochemistry, 74, 21-46, 2005.

Evans, C. D., Davies, T. D., and Wigington, P. J.: Assessing the contribution of individual dissolved ions to depressions in acid neutralising capacity of streams in the Adirondack and Catskill Mountains, New York, Water Air Soil Poll., 85, 425-432, 1995.
Evans, C. D., Cullen, J. M., Alewell, C., Kopácek, J., Marchetto, A., Moldan, F., Prechtel, A., Rogora, M., Veselý, J., and Wright, R.: Recovery from acidification in European surface waters, Hydrol. Earth Syst. Sci., 5, 283-297, 2001a.

Evans, C. D., Monteith, D. T., and Harriman, R.: Long-term variability in the deposition of marine ions at west coast sites in the UK Acid Waters Monitoring Network: Impacts on surface water chemistry and significance for trend determination, Sci. Tot. Environ., 265, 115-129, 2001b.

Evans, C. D., Monteith, D. T., and Cooper, D. M.: Long-term increases in surface water dissolved organic carbon: Observations, possible causes and environmental impacts, Environ. Pollut., 137, 55-71, 2005.

Evans, C. D., Chapman, P. J., Clark, J. M., and Monteith, D. T.: Alternative explanations for rising dissolved organic carbon export from organic soils, Global Change Biol., 12, 2044-2053, 2006.

Freeman, C., Evans, C. D., Monteith, D. T., Reynolds, B., and Fenner, N.: Export of organic carbon from peat soils, Nature, 412, p. 785, 2001.

Harriman, R. and Wells, D. E. W.: Causes and effects of surface water acidification in Scotland, Water Pollut. Control, 84, 215224, 1985.

Hayman, G., Hasler, S., Vincent, K., Baker, S., Donovan, B., Smith, M., Davies, M., Sutton, M., Tang, Y. S., Dragosits, U., Love, L., Fowler, D., Sansom, L., and Page, H.: Operation and Management of the UK Acid Deposition Monitoring Networks: Data Summary for 2000, Report AEAT/ENV/R/0740 Issue 1, AEA Technology, Abingdon, UK, 2000.

Heath, R. H., Kahl, J. S., and Norton, S. A.: Episodic stream acidification caused by atmospheric deposition of sea salts in Acadia National Park, Maine, United States, Water Resour. Res., 28, 1081-1088, 1992.

Hindar, A., Henriksen, A., Torseth, K., and Semb, A.: Acid water and fish death, Nature, 372, 327-328, 1994.

Hindar, A., Torseth, K., Henriksen, A., and Orsolini, Y.: The Significance of the North Atlantic Oscillation (NAO) for Sea-Salt Episodes and Acidification-Related Effects in Norwegian Rivers, Environ. Sci. Technol., 38, 26-33, 2004.

Hughes, S., Reynolds, B., Hudson, J., and Freeman, C.: Effects of summer drought on peat soil solution chemistry in an acid gully mire, Hydrol. Earth Syst. Sci., 1, 661-669, 1997, http://www.hydrol-earth-syst-sci.net/1/661/1997/.

Hulme, M., Jenkins, G. J., Lu, X., Turnpenny, J. R., Mitchell, T. D., Jones, R. G., Lowe, J., Murphy, J. M., Hassell, D., Boorman, P., McDonald, R., and Hill, S.: Climate Change Scenarios for the United Kingdom: The UKCIP02 Scientific Report, Tyndall Centre for Climate Change Research, School of Environmental Sciences, University of East Anglia, Norwich, UK, 2002.

IPCC: Emissions Scenarios: Summary for Policy Makers, Special Report of IPCC Working Group III, ISBN: 92-9169-113-5, 27 pp., 2001.

Jakeman, A. J., Whitehead, P. G., Robson, A., Jenkins, A., and Taylor, J. A.: A method for predicting the extremes of stream acidity and other water quality variables, J. Hydrol., 116, 375-390, 1990.

Jenkins, A., Renshaw, M., Helliwell, R. C., Sefton, C. E. M., Ferrier, R. C., and Swingewood, P.: Modelling surface water acidification in the UK, IH Report No. 131, Institute of Hydrology, Wallingford, 1997. 
Kahl, J. S., Norton, S. A., Haines, T. A., Rochette, E. A., Heath, R. H., and Nodvin, S. C.: Mechanisms of episodic acidification in low-order streams in Maine, USA, Environ. Pollut., 78, 37-44, 1992.

Kerekes, J. and Freedman, B.: Seasonal variations of water chemistry in oligotrophic streams and rivers in Kejimkujik National Park, Nova Scotia, Water Air Soil Pollut., 46, 131-144, 1989.

Langan, S. J.: Sea-salt induced streamwater acidification, Hydrol. Proc., 3, 25-41, 1989.

Laudon, H., Westling, O., and Bishop, K.: Cause of $\mathrm{pH}$ decline in stream water during spring melt runoff in northern Sweden, Can. J. Fish. Aquat. Sci., 57, 1888-1900, 2000.

Lawrence, G. B.: Persistent episodic acidification of streams linked to acid rain effects on soil, Atmos. Environ., 36, 1589-1598, 2002.

Metcalfe, S. E. and Whyatt, J. D.: Modelling future acid deposition with HARM, in: Acid rain and its impact: The critical loads debate, edited by: Battarbee, R. W., 27-36, ENSIS Publishing, London, 1995.

Mitchell, M. J., Driscoll, C. T., Kahl, J. S., Likens, G. E., Murdoch, P. S., and Pardo, L. H.: Climatic control of nitrate loss from forested watersheds in the northeast United States, Environ. Sci. Technol., 30, 2609-2612, 1996.

Molot, L. A., Dillon, P. J., and LaZerte, B. D.: Factors affecting alkalinity concentrations of streamwater during snowmelt in Central Ontario, Can. J. Fish. Aquat. Sci., 46, 1658-1666, 1989.

Monteith, D. T., Evans, C. D., and Reynolds, B.: Are temporal variations in the nitrate content of UK upland freshwaters linked to the North Atlantic Oscillation?, Hydrol. Processes, 14, 17451749, 2000.

Murdoch, P. S. and Stoddard, J. L.: Chemical characteristics and temporal trends in eight streams in the Catskill Mountains, New York, Water Air Soil Poll., 67, 367-395, 1993.

Neal, C.: Introduction to the special issue of Hydrology and Earth System Sciences, the water quality of the Plynlimon catchments, Hydrol. Earth Syst. Sci., 1, 385-388, 1997, http://www.hydrol-earth-syst-sci.net/1/385/1997/.

Neal, C., Robson, A., Reynolds, B., and Jenkins, A.: Prediction of future short-term stream chemistry - a modelling approach, J. Hydrol., 130, 87-103, 1992.

Neal, C., Reynolds, B., Neal, M., Wickham, H., Hill, L., and Williams, B.: The water quality of streams draining a plantation forest on gley soils: the Nant Tanllwyth, Plynlimon mid-Wales, Hydrol. Earth Syst. Sci., 8, 485-502, 2004, http://www.hydrol-earth-syst-sci.net/8/485/2004/.

Räisänen, J., Hansson, U., Ullerstig, A., Döscher, R., Graham, L. P., Jones, C., Meier, H. E. M., Samuelsson, P., and Willén, U.: European climate in the late 21 st century: regional simulations with two driving global models and two forcing scenarios, Clim. Dynam., 22, 13-31, 2004.

Reuss, J. O., Cosby, B. J., and Wright, R. F.: Chemical processes governing soil and water acidification, Nature, 329, 27-31, 1987.

Reynolds, B.: Predicting soil acidification using the SAFE model, Hydrol. Earth Syst. Sci., 1, 717-728, 1997, http://www.hydrol-earth-syst-sci.net/1/717/1997/.

Robson, A., Jenkins, A., and Neal, C.: Towards predicting future episodic changes in stream chemistry, J. Hydrol., 125, 161-174, 1991.

Schaefer, D. A., Driscoll, C. T., Van Dreason, R., and Yasko, C. P.:
The episodic acidification of Adirondack lakes during snowmelt, Water Resour. Res., 26, 1639-1647, 1990.

Schindler, D. W., Curtis, P. J., Bayley, S. E., Parker, B. R., Beaty, K. G., and Stainton, M. P.: Climate-induced changes in the dissolved organic carbon budgets of boreal lakes, Biogeochem., 36, 9-28, 1997.

Schofield, C. L., Galloway, J. N., and Hendry, G. R.: Surface water chemistry of the ILWAS basins, Water, Air, Soil Pollut., 2, 403423, 1985.

Skartveit, A.: Relationships between precipitation chemistry, hydrology, and runoff acidity, Nordic Hydrol., 12, 65-80, 1981.

Skeffington, R. A. and Brown, D. J. A.: Timescales of recovery from acidification - implications of current knowledge for aquatic organisms, Environ. Pollut., 77, 227-234, 1992.

Skjelkvåle, B. L., Stoddard, J., Jeffries, D., Tørseth, K., Høgåsen, T., Bowman, J., Mannio, J., Monteith, D. T., Mosello, R., Rogora, M., Rzychon, D., Vesely, J., Wieting, J., Wilander, A., and Worsztynowicz, A.: Regional scale evidence for improvements in surface water chemistry 1990-2001, Environ. Pollut., 137, 165-176, 2005.

Stoddard, J. L.: Long-term changes in watershed retention of nitrogen, in: Environmental Chemistry of Lakes and Reservoirs, edited by: Baker, L. A., Advances in Chemistry Series, vol 237 , Washington D.C., American Chemical Society, 223-284, 1994.

Stoddard, J. L. and Murdoch, P. S.: Catskill Mountains, in: Acidic Deposition and Aquatic Ecosystems, Regional Case Studies, edited by: Charles, D. F., Springer-Verlag, New York, 237-271, 1991.

VanSickle, J., Wigington, P. J., and Church, M. R.: Estimation of episodic stream acidification based on monthly or annual sampling, J. Am. Water Resour. Assoc., 33, 359-366, 1997.

Wigington, P. J., Davies, T. D., Tranter, M., and Eshleman, K. N.: Episodic acidification of surface waters due to acid deposition, National Acid Precipitation Assessment Program, Washington, D.C., State of Sci/Technol Rep. No. 12, 1990.

Wigington, P. J., Davies, T. D., Tranter, M., and Eshleman, K. N.: Comparison of episodic acidification in Canada, Europe and the United States, Environ. Pollut., 78, 29-35, 1992.

Wigington, P. J., DeWalle, D. R., Murdoch, P. S., Kretser, W. A., Simonin, H. A., VanSickle, J., and Baker, J. P.: Episodic acidification of small streams in the northeastern United States: Ionic controls of episodes, Ecol. App., 6, 389-407, 1996.

Worrall, F., Harriman, R., Evans, C. D., Watts, C. D., Adamson, J., Neal, C., Tipping, E., Burt, T., Grieve, I., Monteith, D., Naden, P. S., Nisbet, T., Reynolds, B., and Stevens, P.: Trends in dissolved organic carbon in UK rivers and lakes, Biogeochem., 70, 369402, 2004.

Wright, R. F.: The decreasing importance of acidification episodes with recovery from acidification: an analysis of the 30-year data record from Birkenes, Norway, Hydrol. Earth Syst. Sci., 12, this special issue, 2008.

Wright, R. F., Alewell, C., Cullen, J., Evans, C., Marchetto, A., Moldan, F., Prechtel, A., Rogora, M.: Trends in nitrogen deposition and leaching in acid-sensitive streams in Europe, Hydrol. Earth Syst. Sci., 5, 299-310, 2001, http://www.hydrol-earth-syst-sci.net/5/299/2001/.

Wright, R. F., Norton, S. A., Brakke, D. F., and Frogner, T.: Experimental verification of episodic acidification of freshwaters by sea salts, Nature, 334, 422-424, 1988. 